\title{
PENGARUH MODEL PEMBELAJARAN QUANTUM TEACHING \\ TERHADAP HASIL BELAJAR SISWA PADA TEMA DAERAH TEMPAT TINGGALKU KELAS IV SD NEGERI 050600 KUALA TAHUN PEMBELAJARAN 2018/2019
}

\section{Dornani Defiana Br. Sitanggang (PGSD FKIP UNIVERSITAS KATOLIK SANTO THOMAS)}

\begin{abstract}
The problem in this study is that student learning outcomes are still low on the theme of the area where I live in class IV 050600 Kuala State Elementary School. The purpose of this study was to determine the effect of the Quantum Teaching learning model on student learning outcomes on the theme of the area where I live in class IV 050600 Kuala State Elementary School the learning year 2018/2019. This type of research is a quantitative research experimental model with a pretest-posttest Control Group Design research design. The class that becomes the population in this study is class IV-A and class IV B, where the population is 39 students with class IV A 18 students, and class IV B 21 students. Sampling uses a simple random sampling technique, and class IV B is selected as a class given treatment. To find out the hypothesis in this study using a different test independent sample t-test in SPSS ver 22.

The results showed that the experimental class experienced a learning increase of $42 \%$ from the previous pretest. In the experimental class the pretest results were 58.85 and posttest was 83.61. This is supported by the results of testing the correlation coefficient. It can be seen that the correlation coefficient value is 0.772 , which means that it is calculated $(0.772)>r_{\text {table }}(0.433)$ then $\mathrm{H}_{\mathrm{a}}$ is accepted. Then there is a strong relationship and there is an influence the Quantum Teaching model on learning outcomes in class IV 050600 Kuala State Elementary School. Can also be seen from the results of testing the hypothesis ttest where $t_{\text {count }}>t_{\text {table }}$ is $33,035>1,687$ so that the hypothesis $H_{a}$ is accepted. This shows the influence of the Quantum Teaching learning model on student learning outcomes on the theme of the area where I live in class IV 050600 Kuala State Elementary School in the 2018/2019 learning year.
\end{abstract}

Keywords: Influence, Quantum Teaching, Learning Outcomes, Where I Live.

\section{PENDAHULUAN}

\section{Latar Belakang}

Pendidikan sangat penting bagi kehidupan manusia.Salah satu alasan pentingnya pendidikan bagi kehidupan manusia, yaitu dengan adanya pendidikan manusia dapat memiliki pengetahuan tentang berbagai hal.Pendidikan juga berperan penting dalam meningkatkan kualitas dan keberhasilan suatu bangsa.Jika 
pendidikan di dalam suatu bangsa atau negara tersebut baik, maka dapat meningkatkan kualitas bangsa tersebut.

Undang-undang Republik Indonesia tentang Sistem Pendidikan Nasional No. 20 Tahun 2003 pasal 1 ayat 1, dinyatakan bahwa pendidikan adalah usaha sadar dan terencana untuk mewujudkan suasana belajar dan proses pembelajaran agar siswa secara aktif mengembangkan potensi dirinya untuk memiliki kekuatan spiritual keagamaan, pengendalian diri, kepribadian, kecerdasan, akhlak mulia, serta keterampilan yang diperlukan dirinya, masyarakat, bangsa, dan negara (Surahman dan Mukmian, 2017: 2)

Pendidikan tidak semata-mata hanya sebagai sarana untuk persiapan kehidupan masa depan, tetapi juga untuk kehidupan anak-anak sekarang yang sedang mengalami perkembangannya menuju tingkat kedewasaan. Pendidikan sangat mempengaruhi kemampuan kepribadian serta kehidupan seseorang dalam pergaulan sehari-hari di masyarakat.Hal ini menunjukkan bahwa pendidikan memiliki banyak manfaat dan sebagai salah satu langkah yang dilakukan untuk membentuk manusia yang cerdas dan berkualitas.Di Indonesia terdapat tiga jenjang pendidikan yaitu pendidikan dasar, pendidikan menengah, dan pendidikan tinggi.Menurut Suharjo (Ningrum, 2017: 2) "Pendidikan di Sekolah Dasar (SD) adalah upaya pembekalan kemampuan dasar siswa berupa pengetahuan, keterampilan, dan sikap yang bermanfaat bagi dirinya seiring dan sesuai tingkat perkembangannya, serta mempersiapkan siswa untuk melanjutkan ke jenjang yang lebih tinggi".

Dalam pendidikan, kurikulum merupakan salah satu komponen yang sangat menentukan dalam suatu sistem pendidikan, karena itu kurikulum merupakan alat untuk mencapai tujuan pendidikan dan sekaligus sebagai pedoman dalam pelaksanaan pengajaran pada semua jenis dan tingkat pendidikan. Pengertian Kurikulum itu sendiri adalah perangkat mata pelajaran dan program pendidikan, yang diberikan oleh suatu lembaga penyelenggara pendidikan, yang berisi rancangan pelajaran dan akan diberikan kepada peserta pelajaran dalam satu periode jenjang pendidikan. Kurikulum yang kita pakai sekarang ini adalah kurikulum 2013, yang berbasis karakter dan kompetensi yang mewajibkan anak untuk aktif dalam pembelajaran.Pada penerapan kurikulum 2013, pembelajaran 
tematik merupakan suatu pendekatan yang mengaitkan beberapa mata pelajaran dalam satu tema.Dalam penerapan pembelajaran Tematik, menekankan pada prinsip belajar sambil melakukan (learning by doing) serta menggunakan aktivitas pendekatan ilmiah (saintific approuch).Pendekatan scientific yaitu pendekatan yang berpusat pada siswa.Pada penerapan kurikulum 2013, kreativitas guru merupakan salah satu kunci sukses dalam keberhasilan penerapan kurikulum 2013.Guru di harapkan dapat memilih metode maupun model pembelajaran yang baik dan tepat sehingga proses pembelajaran dapat berjalan dengan efektif dan berhasil dengan baik. Guru di tuntut untuk dapat menciptakan suasana pembelajaran yang menyenangkan dan bermakna bagi siswa. Guru harus kreatif dan inovatif serta mampu menumbuhkan minat belajar siswa sehingga memudahkan siswa dalam belajar dan meningkatkan prestasi belajar siswa.

Berdasarkan hasil observasi yang peneliti lakukan di SD Negeri 050600 Kuala di kelas IV-B, peneliti melihat bahwa cara mengajar guru di dalam kelas kurang menarik. Guru masih menggunakan model ceramah dalam proses pembelajaran. Setelah selesai menyampaikan materi, guru memberikan tugas atau soal kepada siswa untuk dikerjakan.Dalam kegiatan pembelajaran yang berlangsung tersebut peneliti dapat melihat bahwa siswa banyak yang bosan, terlebih juga banyak siswa yang berbicara dan menggangu temanya.Guru yang kurang memanfaatkan model pembelajaran inovatif lainnya, membuat pembelajaran yang berlangsung kurang menarik perhatian siswa dan siswa kurang termotivasi dalam belajar. Hal ini dikarenakan pembelajaran cenderung berpusat pada guru (teacher centered).

Berdasarkan hasil wawancara peneliti dengan guru wali kelas IV-B yang bernama Ibu Ria, peneliti melihat hasil belajar siswa kelas IV-B masih rendah dan belum memuaskan yang rata-rata nilai belajarnya masih belum mencapai Kriteria Ketuntasan Minimal (KKM) yaitu 75. Agar lebih jelas, peneliti memapaparkan nilai hasil belajar siswa pada pembelajaran tema daerah tempat tinggalku pada tabel berikut ini. Berdasarkan data nilai hasil belajar siswa, yang peneliti peroleh dari guru kelas IV-B yang bernama ibu Ria, dapat di lihat bahwa KKM yang di tentukan di sekolah tersebut adalah 75. Siswa kelas IV-B yang berada di SD 
Negeri 050600 Kuala berjumlah 19 orang. Dari 19 orang siswa, yang mencapai KKM pada mata pelajaran IPA sebanyak 4 orang siswa, dan pada mata pelajaran Bahasa Indonesia sebanyak 8 orang siswa. Sedangkan siswa yang tidak mencapai KKM pada mata pelajaran IPA sebanyak 15 orang siswa, dan pada mata pelajaran Bahasa Indonesia sebanyak 11 orang siswa. Dari data ini, dapat kita lihat bahwa masih rendahnya nilai hasil belajar siswa yang belum memenuhi KKM pada tema daerah tempat tinggalku.Maka dari itu diperlukan perubahan dalam penyampaikan materi pembelajaran bagi siswa.Perlu digunakan model pembelajaran yang alternatif yaitu model pembelajaran yang tepat agar siswa tertarik dan tidak mudah bosan terhadap mata pelajaran yang sedang berlangsung dan mudah menyerap materi yang diajarkan sehingga dapat meningkatkan hasil belajar siswa khususnya pada tema daerah tempat tinggalku.Salah satu model pembelajaran inovatif yang dapat digunakan tersebut adalah model pembelajaran Quantum Teaching.

Model pembelajaran Quantum Teaching merupakan model percepatan belajar (accelerated learning) yang membiasakan belajar nyaman dan menyenangkan. Model Quantum Teaching memiliki rumusan pembelajaran yang menjadi langkah-langkah dalam proses pembelajaran. Rumusan tersebut dikenal dengan rumusan Tumbuhkan, Alami, Namai, Demonstrasikan, Ulangi dan Rayakan (TANDUR). Dengan diterapkannya tiap langkah model Quantum Teaching dengan baik maka siswa akan dilibatkan secara aktif dalam kegiatan pembelajaran. Selain itu siswa juga akan belajar dalam suasana yang meriah dan menyenangkan sehingga siswa tidak akan mudah merasa jenuh selama kegiatan pembelajaran berlangsung. Kelebihan dari model Quantum Teaching adalah, menciptakan semangat belajar, membuat siswa aktif mengamati, menyesuaikan antara teori dan kenyataan, dan dapat mencoba melakukannya sendiri, juga meningkatkan kerjasama antar siswa. Melalui model Quantum Teaching diharapkan mampu mengatasi berbagai permasalahan yang ada pada proses pembelajaran dengan tema Daerah tempat tinggalku.

Berdasarkan penelitian yang dilakukan oleh Andini (2016), model pembelajaran Quantum Teaching bepengaruh signifikan terhadap hasil belajar 
siswa.Hasil penelitian menunjukkan bahwa penelitian yang dilakukan oleh Andini memberikan hasil yang diharapkan pada mata pelajaran IPA. Berdasarkan latar belakang di atas, peneliti tertarik untuk mengetahui pengaruh penggunaan model Quantum Teaching terhadap hasil belajar siswa. Maka peneliti akan melakukan penelitian dengan judul penelitian "Pengaruh Model Pembelajaran Quantum Teaching terhadap Hasil Belajar siswa pada tema Daerah Tempat Tinggalku di Kelas IV SD Negeri 050600 Kuala Tahun Pembelajaran 2018/2019”.

\section{Identifikasi Masalah}

Berdasarkan latar belakang masalah tersebut dapat diidentifikasikan beberapa masalah yaitu:

1. Guru masih menjelaskan dengan menggunakan model ceramah. Sehingga membuat siswa menjadi bosan dalam belajar dan siswa kurang termotivasi untuk belajar.

2. Guru kurang memanfaatkan model pembelajaran inovatif lainnya dalam pembelajaran.

3. Dalam menerapkan pembelajaran guru belum aktif dan kreatif melibatkan siswa dan lebih cenderung pembelajaran berpusat pada guru (teacher centered).

4. Hasil belajar siswa masih tergolong rendah pada Tema Daerah Tempat Tinggalku.

\section{Pembatasan Masalah}

Berdasarkan identifikasi masalah di atas, peneliti membatasi permasalahan yang diteliti, Adapun batasan masalah dalam penelitian ini adalah Pengaruh Model Pembelajaran Quantum Teaching Terhadap Hasil Belajar Siswa Pada Tema Daerah Tempat Tinggalku Di Kelas IV SD Negeri 050600 Kuala Tahun Pembelajaran 2018/2019.

\section{Rumusan Masalah}

Berdasarkan identifikasi dan batasan masalah di atas, dapat dirumuskan masalah penelitian sebagai berikut: Apakah ada pengaruh model pembelajaran Quantum Teaching terhadap hasil belajar siswa pada tema daerah tempat tinggalku di kelas IV SD Negeri 050600 kuala tahun pembelajaran 2018/2019? 


\section{Tujuan Penelitian}

Berdasarkan rumusan masalah di atas, maka tujuan dari penelitian ini adalah: Untuk mengetahui pengaruh model pembelajaran Quantum Teaching terhadap hasil belajar dengan Tema Daerah Tempat Tinggalku pada siswa kelas IV SD Negeri 050600 Kuala pada tahun pembelajaran 2018/2019.

\section{Manfaat Penelitian}

Hasil penelitian yang dilakukan diharapkan dapat bermanfaat secara teoritis maupun praktis.Manfaat teoritis artinya hasil penelitian bermanfaat untuk mengembangkan ilmu pengetahuan.Manfaat praktis bermanfaat bagi berbagai pihak untuk memperbaiki kinerja, terutama bagi sekolah, guru, siswa dan peneliti.

1. Manfaat Teoritis, antara lain:

a. Adanya penemuan solusi pemecahan masalah yang terjadi di dalam proses pembelajaran di kelas.

b. Menggunakan model pembelajaran yang baru dan bervariasi untuk meningkatkan belajar.

2. Manfaat Praktis, antara lain:

a. Bagi Siswa

Melalui model Quantum Teaching, diharapkan siswa dapat memperoleh pembelajaran bermakna.

b. Bagi Guru

Model Quantum Teaching dapat dijadikan sebagai salah satu alternatif dalam melakukan inovasi pembelajaran.Dapat menciptakan pembelajaran menyenangkan dan bermakna.

c. Bagi Sekolah

Menjadi referensi bagi pihak sekolah dalam upaya meningkatkan mutu pembelajaran di SD Negeri 050600 Kuala.

d. Bagi Peneliti

Hasil penelitian ini diharapkan menjadi sebuah ilmu dan pengalaman sebagai dasar untuk mengadakan penelitian lebih lanjut. 


\section{METODOLOGI PENELITIAN}

\section{Pendekatan dan Metode Penelitian}

\section{Pendekatan Penelitian}

Jenis pendekatan yang dilakukan dalam penelitian ini adalah pendekatan kuantitatif. Menurut Noor (2013: 38) "Penelitian kuantitatif adalah data penelitian yang terdiri dari angka-angka yang dapat dianalisis berdasarkan prosedur statistik".

\section{Metode Penelitian}

Adapun metode penelitian yang digunakan dalam penelitian ini adalah penelitian eksperimen. Metode dalam penelitian ini sangat penting karena dengan menggunakan metode ini, akan menjadikan bahan bukti untuk peneliti. Dalam penelitian ini, peneliti menggunakan metode kuantitatif jenis eksperimen. Menurut Noor (2013: 42) "Penelitian eksperimen merupakan metode inti dari model penelitian yang menggunakan pedekatan kuantitatif'. Eksperimental merupakan suatu percobaan yang dilakukan dalam suatu penelitian. Menurut Sugiyono "Dalam penelitian eksperimen ada perlakuan (treatment)". Dengan demikian metode penelitian eksperimen dapat diartikan sebagai metode penelitian yang digunakan untuk mencari pengaruh perlakuan tertentu terhadap yang lain dalam kondisi yang terkendalikan. Menurut Noor (2013: 42) "Dalam penelitian eksperimen, peneliti membagi objek atau subjek yang diteliti menjadi dua kelompok yaitu kelompok treatment yang mendapatkan perlakuan dan kelompok kontrol yang tidak mendapatkan perlakuan”. Dalam penelitian ini menggunakan model eksperimen dengan dua kelompok yaitu kelas eksperimen yang diberi perlakuan dengan menggunakan model Quantum Teaching dan kelas kontrol yang tidak diberi perlakuan menggunakan model konvensional.

\section{Lokasi dan Jadwal Penelitian}

\section{Lokasi penelitian}

Lokasi adalahtempat dimana peneliti melakukan penelitian.Penelitian ini dilaksanakan di SD Negeri 050600 Kuala.Yang beralamat di Jalan Gajah Mada No 72 Kuala. 


\section{Jadwal penelitian}

Penelitian ini dilaksanakan pada semester genap pada bulan Maret sampai April Tahun 2019. Kegiatan penelitian ini dapat dilihat dari tabel berikut:

\section{Rancangan/Desain Penelitian}

Rancangan/desain dalam sebuah penelitian berguna untuk mengambil keputusan sebelum kegiatan dilakukan. Dalam penelitian ini, desain penelitian digunakan untuk mencari pengaruh perlakuan tertentu terhadap yang lain dalam kondisi terkendali. Dalam penelitian ini terdapat variabel bebas dan variabel terikat. Menurut Sugiyono (2017: 61) "Variabel bebas (Independen) adalah variabel yang mempengaruhi atau yang menjadi sebab perubahannya atau timbulnya veriabel terikat (Dependen), sedangkan variabel terikat (Dependen) adalah variabel yang dipengaruhi atau yang menjadi akibat, karena adanya variabel bebas (Independen)". Variabel bebas biasanya disimbolkan dengan X sedangkan variabel terikat disimbolkan dengan Y,dengan judul penelitian "Pengaruh Model Pembelajaran Quantum Teaching Terhadap Hasil Belajar Siswa Pada Tema Daerah Tempat Tinggalku Di Kelas IV SD Negeri 050600 Kuala Tahun Pembelajaran 2018/2019”,

Berdasarkan uraian di atas maka dapt digambarkan desain penelitian seperti pada gambar berikut ini:

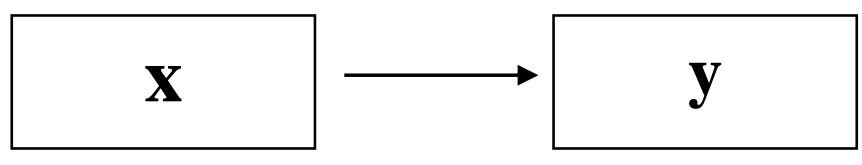

\section{keterangan:}

X : Model Quantum Teaching

Y : Hasil Belajar

\section{Populasi dan Teknik Pengambilan Sampel}

\section{Populasi}

Arikunto (Mungkur, 2018: 23) menyatakan bahwa "Populasi adalah seluruh aspek penelitian". Menurut Sugiyono (2017: 117) "Populasi adalah wilayah generalisasi yang terdiri atas objek/subjek yang mempunyai kualitas dan 
karakteristik tertentu yang ditetapkan oleh peneliti untuk dipelajari dan kemudian ditarik kesimpulannya". Populasi dalam penelitian ini adalah siswa-siswi kelas IV di SD Negeri 050600 Kuala yang terdiri dari dua kelas seperti yang terlihat pada tabel berikut ini.

\section{Keadaan Peserta Didik Kelas IV di SD Negeri 050600 Kuala Tahun Pembelajaran 2018/2019}

\begin{tabular}{|c|c|c|}
\hline No & Kelas & Jumlah \\
\hline 1. & IV-A & 18 \\
\hline 2. & IV-B & 21 \\
\hline Jlh & & 39 \\
\hline
\end{tabular}

\section{Sampel}

Sampel adalah sebagian dari jumlah populasi yang diambil menggunakan cara-cara tertentu.Sugiyono (2017: 118) menyatakan bahwa "Sampel adalah bagian dari jumlah dan karakteristik yang dimiliki oleh populasi tersebut". Bila populasi besar, dan peneliti tidak mungkin mempelajari semua yang ada pada populasi, misalnya karena keterbatasan dana, tenaga, dan waktu, maka peneliti dapat menggunakan sampel yang diambil dari populasi itu. Berdasarkan teknik simpel random sampling terpilih kelas IV B sebagai sampel pada penelitian ini.Adapun kelas yang menjadi sampel penelitian adalah kelas IV-A dan kelas IVB. Kelas IV-A menjadi kelas kontrol dan kelas IV-B menjadi kelas eksperimen. Sehingga jumlah sampel dalam penelitian ini sama dengan jumlah populasi siswa kelas IV yang ada di SD Negeri 050600 Kuala yaitu sebanyak 39 siswa. Dapat kita lihat pada tabel dibawah ini.

\section{Jumlah Sampel Penelitian}

\begin{tabular}{|c|l|c|c|}
\hline No & Kelas & Kategori & Jumlah \\
\hline 1 & IV-A & Kelas Kontrol & 18 \\
\hline 2 & IV-B & Kelas Eksperimen & 21 \\
\hline \multicolumn{3}{|c|}{ Jumlah } & 39 \\
\hline
\end{tabular}

\section{Jenis dan Sumber Data}

\section{Jenis Data}

Data adalah hasil pencatatan penelitian, baik yang berupa fakta maupun angka. Menurut Sugiyono (2018: 193) "Jenis data terbagi atas dua yaitu data 
primer dan data sekunder." Data primer adalah data yang langsung memberikan data kepada pengumpul data.Data sekunder adalah data yang tidak langsung memberikan data pada pengumpul data.Jenis data pada penelitian ini adalah jenis data primer yaitu data berupa hasil belajar siswa yang dilakukan peneliti secara langsung.

\section{Sumber Data}

Menurut Arikunto (2018: 29) "Sumber data dalam penelitian adalah subyek darimana data diperoleh". Dalam peneltian ini, sumber data yang digunakan peneliti diperoleh dari SD Negeri 050600 Kuala.Jumlah populasi sebanyak 39 orang siswa yang berada di kelas IV-A dan IV-B.

\section{Teknik dan Alat Pengumpulan Data}

Teknik Pengumpulan data merupakan cara yang dapat digunakan oleh peneliti untuk mengumpulkan data. Sugiyono (2018: 193) menyatakan bahwa "Pengumpulan data dapat dilakukan dalam berbagai setting, berbagai sumber dan berbagai cara". Menurut Sugiyono (2017: 308) "Teknik pengumpulan data merupakan langkah yang paling utama dalam penelitian karena tujuan utama dari penelitian adalah mendapatkan data".Dalam penelitian ini peneliti menggunakan teknik pengumpulan data secara observasi, wawancara, studi dokumentasi dan tes.

\section{Observasi}

Menurut Sudjana (2016: 85) "Ada tiga jenis observasi, yakni observasi langsung, observasi dengan alat (tidak langsung), dan observasi partisipasi”. Observasi langsung adalah pengamatan yang dilakukan terhadap gejala atau proses yang terjadi dalam situasi yang sebenarnya dan langsung diamati oleh pengamat. Sedangkan observasi tidak langsung dilaksanakan dengan menggunakan alat seperti mikroskop untuk mengamati bakteri.Observasi partisipasi berarti bahwa pengamatan harus melibatkan diri atau ikut serta dalam kegiatan yang dilaksanakan oleh individu atau kelompok yang diamati.

\section{Wawancara}

Menurut Sudjana (2016: 68) "Ada dua jenis wawancara, yakni wawancara berstruktur dan wawanca bebas (tak berstruktur).Dalam wawancara berstrukur kemungkinan jawaban telah disiapkan, sehingga siswa tinggal 
mengkategorikannya kepada alternatif jawaban yang telah dibuat.Keuntungannya ialah mudah diolah dan dianalisis untuk dibuat kesimpulan.Sedangkan pada wawancara bebas, jawaban tidak perlu disiapkan sehingga siswa bebas mengemukakan pendapatnya.Keuntungannya ialah informasi lebih padat dan lengkap sekalipun itu harus bekerja keras dalam menganalisisnya sebab jawabanya bisa beraneka ragam.Pada penelitian ini peneliti melakukan wawancara dengan guru kelas IV yang berada di SD Negeri 050600 Kuala untuk mengetahui informasi yang dibutuhkan. Peneliti bertanya mengenai, berapa jumlah siswa di kelas tersebut, sudah sampai dimana materi yang sedang berlangsung, bagaimana minat belajar siswa tersebut, menanyakan mengenai nilai hasil belajar siswa, peneliti juga bertanya kepada kepala sekolah, apakah sudah pernah ada dilakukan penelitian di sekolah tersebut dengan menggunakan model pembelajaran Quantum Teaching atau tidak.

\section{Studi Dokumentasi}

Studi dokumentasi adalah mengumpulkan sejumlah dokumen yang diperlukan sebagai bahan data informasi sesuai dengan masalah penelitian, seperti peta, data statistik, jumlah dan nama pegawai, data siswa, data penduduk, grafik, gambar, surat-surat, foto, dan akte. Menurut Bogdan (Nilamsari, 2014: 178) "Dokumen merupakan catatan peristiwa yang telah berlalu, bisa berbentuk tulisan, gambar, karya-karya monumental dari seseorang". Dari pengertian di atas dapat disimpulkan bahwa dokumen merupakan sumber data yang digunakan untuk melengkapi penelitian, baik berupa sumber tertulis, film, gambar (foto), dan karya-karya monumental, yang semuanya itu memberikan informasi bagi proses penelitian. Pada penelitian ini, peneliti meminta arsip nilai hasil ujian semester siswa kelas IV di SD Negeri Kuala pada tahun pembelajaran 2017/2018.

Tes

Tes merupakan salah satu cara yang peneliti lakukan untuk mengumpulkan data. Tes yang digunakan dalam penelitian ini adalah tes tertulis dalam bentuk soal pilihan berganda.Tes tersebut terdiri dari 50 butir soal.Menurut Sudjana (2016: 35) "Tes sebagai alat penilaian adalah pertanyaan-pertanyaan yang diberikan kepada siswa untuk mendapat jawaban dari siswa dalam bentuk lisan 
(tes lisan), dalam bentuk tulisan (tes tulisan), atau dalam bentuk perbuatan (tes tindakan)".Menurut Arikunto (Mungkur, 2018: 29) "Instrument yang berupa tes ini dapat digunakan untuk mengukur kemampuan dasar dan pencapaian atau prestasi”.

\section{Angket}

Merupakan suatu teknik pengumpulan data dengan memberikan atau menyebarkan daftar pertanyaan kepada responden. Menurut Sugiono (2018: 137) kuisioner merupakan teknik pengumpulan data yang dilakukan dengan cara memberi seperangkat pertanyaan atau pernyataan tertulis kepada siswa yang akan dijawab oleh siswa. Pertanyaan atau pernyataan yang akan diberikan oleh peneliti kepada siswa nantinya berjumlah 15 butir (terlampir).

Pada penelitian ini peneliti menggunakan skala likert dalam menentukan nilai atau sikap dalam setiap jawaban yang terdapat pada angket yang akan dibagikan. Menurut Riduan (2010: 12) "Skala likert digunakan untuk mengukur sikap, pendapat dan persepsi seseorang atau kelompok tentang kejadian atau gejala sosial."

\section{Uji Instrument Tes}

\section{Uji Validitas Tes}

Uji coba tes dilakukan untuk mengukur kualitas tes, sebelum tes digunakan untuk mengumpulkan data penelitian. Untuk menguji kualitas instrument peneliti dapat menggunakan alat ukur berupa validitas dan reliabilitas. Menurut Noor (2013: 132) "Validitas adalah suatu indeks yang menunjukkan alat ukur tersebut benar-benar mengukur apa yang diuku”. Validitas berasal dari kata valid yang mempunyai arti sejauh mana tes mampu mengukur apa yang hendak diukur. Untuk mengetahui apakah kuesioner tersebut valid, maka perlu diuji dengan uji korelasi antara skor (nilai) tiap-tiap butir pertanyaan dengan skor total kuisioner tersebut. Adapun teknik korelasi yang biasa dipakai adalah teknik korelasi product moment dan untuk mengetahui apakah nilai korelasi tiap-tiap pertanyaan itu significant, maka dapat dilihat pada tabel nilai product moment atau menggunakan SPSS untuk mengujinya. Rumus product moment adalah sebagai berikut: 


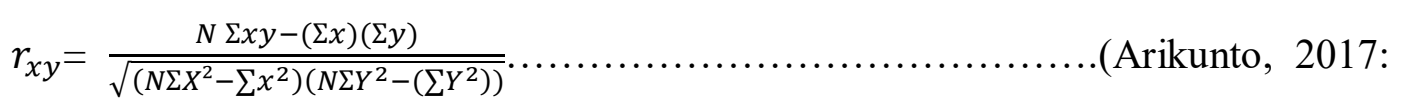

87)

Keterangan:

$r_{x y}=$ Koefisien korelasi $\mathrm{x}$ dan $\mathrm{y}$

$\mathrm{N}$ = Jumlah responden / banyak siswa peserta tes

$\mathrm{X}=$ Jumlah skor diperoleh siswa untuk tiap item soal

$\mathrm{Y}=$ Jumlah skor total yang benar

\section{Uji Reliabilitas Tes}

Menurut jihad dan haris (2013: 180) "Reliabilitas soal merupakan ukuran yang menyatakan tingkat keajegan atau kekonsistenan suatu tes". Untuk menguji reliabilitas tes dalam penelitian digunakan rumus Alpha sebagai berikut:

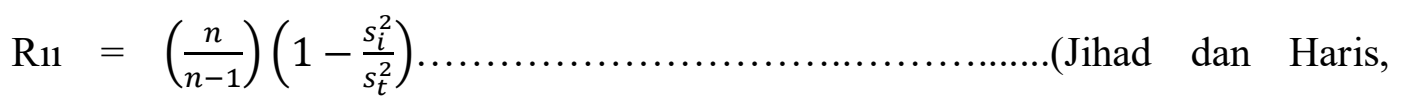
2013:180)

Keterangan:

R11 = Reliabilitas instrument

$\mathrm{n} \quad=$ Banyak nya butir soal

$s_{i}^{2} \quad=$ jumlah varians skor tiap item

$s_{t}^{2} \quad=$ varians skor total

\section{Uji Daya Pembeda Tes}

Dalam instrument tes daya pembeda adalah untuk mengkaji soal-soal tes dari segi kesanggupan tes tersebut dalam membedakan siswa yang termaksud ke dalam kategori lemah/rendah dan kategori kuat/tinggi prestasinya.

Untuk perhitungan daya pembeda (DP), dilakukan langkah-langkah sebagai berikut:

1. Para siswa didaftarkan dalam peringkat pada sebuah tabel

2. Dibuat pengelompokan siswa dalam dua kelompok, yaitu kelompok atas terdiri atas $50 \%$ dari seluruh siswa yang mendapat skor tinggi dan kelompok bawah terdiri atas $50 \%$ dari seluruh siswa yang mendapat skor rendah.

Daya Pembeda ditentukan dengan:

$\mathrm{DP}=\frac{S_{A}-S_{B}}{I_{A}}$ 
Keterangan

$S_{A}=$ Jumlah skor kelompok atas pada butir soal yang diolah

$S_{B}=$ Jumlah skor kelompok bawah pada butir soal yang diolah

$S_{B}=$ Jumlah skor ideal salah satu kelompok pada butir soal yang diolah

Tabel 3.10Interpretasi Nilai Daya Pembeda

\begin{tabular}{|l|l|}
\hline \multicolumn{1}{|c|}{ Koefisien Korelasi } & \multicolumn{1}{|c|}{ Makna } \\
\hline 0,40 atau lebih & Sangat baik \\
\hline $0,30-0,39$ & Cukup baik, mungkin perlu diperbaiki \\
\hline $0,20-0,29$ & Minimum, perlu diperbaiki \\
\hline 0,19 ke bawah & Jelek, dibuang atau dirombak \\
\hline
\end{tabular}

(Jihad dan haris, 2013: 181)

\section{Uji Tingkat Kesukaran Tes}

Tingkat kesukaran pada masing-masing butir soal dihitung dengan menggunakan rumus:

$\mathrm{TK}=\frac{S_{A}+S_{B}}{n \text { maks }}$

Keterangan:

TK = Tingkat Kesukaran

$S_{A} \quad=$ Jumlah skor kelompok atas

$S_{B} \quad=$ Jumlah skor kelompok bawah

$\mathrm{n}=$ Jumlah siswa kelompok atas dan kelompok bawah

maks $=$ Skor maksimal soal yang bersangkutan

Tabel 3.11 Kriteria Tingkat Kesukaran

\begin{tabular}{|c|c|}
\hline TK & Tingkat Kesukaran \\
\hline $0,00-0,30$ & Sukar \\
\hline $0,31-0,70$ & Sedang \\
\hline $0,71-1,00$ & Mudah \\
\hline
\end{tabular}

(Jihad dan haris, 2013: 182) 


\section{Uji Prasyarat}

\section{Uji Normalitas}

Uji normalitas dilakukan untuk mengetahui apakah populasi terdistribusi normal apa tidak. Uji normalitas dilakukan dengan menggunakan uji Lilliefoors, Sudjana (2017: 446-467) Langkah-langkah seperti berikut ini.

a. Data hasil belajar $\mathrm{X}_{1} \mathrm{X}_{2} \mathrm{X}_{3} \ldots \mathrm{X}_{\mathrm{n}}$ dijadikan bilangan baku Z1, Z2,Z3,.... Zn dengan menggunakan rumus) sebagai berikut:

$\mathrm{Zi}=\frac{X_{i}-x}{S D}$

Keterangan:

$\bar{X}$ : Rata-rata

$S$ : Simpangan Baku

b. Tiap bilangan baku dihitung dengan menggunakan daftar distribusi normal kemudian dihitung peluang dengan rumus: $F(Z i)=\mathrm{P}(\mathrm{Z} \geq \mathrm{Zi})$.

c. Selanjutnya menghitung proporsi $\mathrm{Z1}, \mathrm{Z2}, \mathrm{Z3}, \ldots \ldots . \mathrm{Zn}$ yang lebih kecil atau sama dengan $\mathrm{Z1}$. Jika proporsi itu menyatakan dengan $S(Z i)$, maka:

$S(Z i),=\frac{\text { banyak } Z 1, Z 2, Z 3, \ldots . . Z n \text { yang } \leq \mathrm{Z} 1}{n}$

d. Menghitung selisih F ( $\mathrm{Z}$ i) - ( $\mathrm{Z}$ i), kemudian menentukan harga mutlaknya.

e. Ambil harga yang paling besar antara selisih tersebut dengan L0 : untuk menerima atau menolak hipotesis, kemudian membandingkan L0 dengan nilai kritis yang di ambil dari daftar, untuk taraf nyata $\alpha=0,05$

Dengan kriteria:

Jika $L_{\text {hitung }}<L_{\text {tabel }}$ maka sampel berdistribusi normal

Jika $L_{\text {hitung }}>L_{\text {tabel }}$ maka sampel berdistribusi tidak normal.

\section{Uji Homogenitas}

Uji homogenitas adalah dimaksudkan untuk memperlihatkan bahwa dua atau lebih kelompok data sampel berasal populasi yang memiliki varians yang sama. Uji Homogenitas dilakukan dengan rumus yang dinyatakan dari Sudjana (2017: 249) langkah-langkah sebagai berikut:

1. Tuliskan $\mathrm{H}_{\mathrm{a}}$ dan $\mathrm{H}_{0}$ dalam bentuk kalimat

2. Tuliskan $\mathrm{H}_{\mathrm{a}}$ dan $\mathrm{H}_{0}$ dalam bentuk statistik 
3. Menentukan taraf signifikan, dalam penelitian ini taraf signifikasinya adalah $\infty=0.05$.

4. Cari $F_{\text {hitung }}$ dengan rumus:

$$
F_{\text {hitung }}=\frac{\text { Varians Terbesar }}{\text { Varians terkecil }} \text { atau } \mathrm{F}=\frac{s 1^{2}}{s 1^{2}}
$$

Keterangan:

$s 1^{2}=$ Varian dari kelompok yang terbesar

$s 1^{2}=$ Varian dari kelompok terkecil

Kriteria Penelitian

Jika $F_{\text {hitung }}>F_{\text {tabel }}$ maka sampel mempunyai varians yang sama

Jika $F_{\text {hitung }}<F_{\text {tabel }}$ maka sampel tidak mempunyai varians yang sama

\section{Uji Linieritas}

Uji ini biasanya digunakan sebagai prasyarat dalam analisis korelasi atau regresi linier. Adapun rumus uji linieritas adalah sebagai berikut:

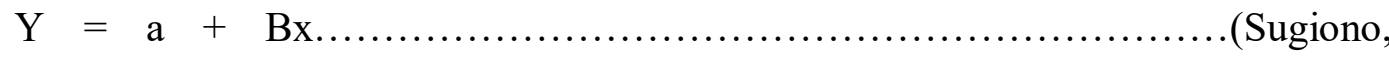

2018:188)

Keterangan:

$$
\begin{array}{ll}
\mathrm{a} & =\text { Konstanta } \\
\mathrm{B} & =\text { Koefisien Regresi } \\
\mathrm{X} & =\text { Variabel Independen } \\
\mathrm{Y} & =\text { Variabel Dependen }
\end{array}
$$

\section{Teknik Pengolahan (Analisis) Data}

Pengolahan data adalah suatu proses untuk memperoleh data ringkasan atau angka ringkasan dengan menggunakan rumus-rumus tertentu. Analisis data dilakukan setelah selesai mengumpulkan data penelitian.Tujuan dari pengolahan data adalah untuk mengubah data mentah dari hasil pengukuran menjadi data yang lebih halus sehingga memberikan arah untuk pengkajian lebih lanjut.Dari hasil di atas maka data yang telah terkumpulkan dianalisis guna mencapai hasil yang maksimal. Analisis tersebut dapat dilakukan seperti langkah-langkah sebagai berikut: 


\section{Uji Koefisien Korelasi}

Untuk mengetahui ada tidaknya pengaruh antara variabel bebas (X) dengan variabel terikat (Y), dengan rumus korelasi Product moment yaitu: sebagai berikut:

$r_{x y}=\frac{N \Sigma x y-(\Sigma x)(\Sigma y)}{\sqrt{\left(N \Sigma X^{2}-\Sigma X\right)^{2}\left(N \Sigma Y^{2}-\Sigma Y\right)^{2}}} \ldots \ldots \ldots \ldots \ldots \ldots \ldots \ldots \ldots \ldots \ldots \ldots \ldots \ldots \ldots \ldots \ldots \ldots \ldots \ldots$ Arikunto, 2017:

87)

Keterangan:

$r_{x y}=$ Koefisien korelasi $\mathrm{x}$ dan $\mathrm{y}$

$\mathrm{N}$ = Jumlah responden / banyak siswa peserta tes

$\mathrm{X}=$ Jumlah skor diperoleh siswa untuk tiap item soal

$\mathrm{Y}=$ Jumlah skor total yang benar

\section{Uji Hipotesis}

Untuk mengetahui apakah variable $\mathrm{X}$ memiliki hubungan yang signifikan (berarti) terhadap variable $\mathrm{Y}$ dilakukan pengujian terhadap hipotesis dengan menggunakan uji-t, Rumus yang digunakan dalam Uji-t adalah sebagai berikut:

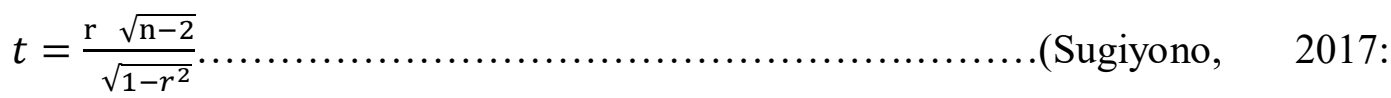

230)

Keterangan:

$\mathrm{r}=$ Koefesien Korelasi

$\mathrm{n}=$ sampel

$\mathrm{t}=\frac{0,772 \sqrt{21-2}}{1-(0,772)^{2}}$

$\mathrm{t}=\frac{0,772 \sqrt{19}}{1-0,595}$

$\mathrm{t}=\frac{(0,772)(4.358)}{0.405}$

$\mathrm{t}=\frac{3.364}{0.405}$

$\mathrm{t}=8,306$ 
Hipotesis diterima, jika $t_{\text {hitung }}>t_{\text {tabel }}$ begitu sebaliknya, jika $t_{\text {hitung }}<t_{\text {tabel }}$, maka hipotesis ditolak. Dengan taraf kesalahan 0,05 atau 5\%.

\section{Prosedur Penelitian}

Prosedur dapat diartikan sebagai langkah-langkah atau jalannya suatu penelitian guna memperoleh data sebagai hal mendasar untuk membuat kesimpulan terhadap suatu hal yang diteliti. Adapun langkah-langkah dalam penelitian ini adalah sebagai berikut:

\section{Bagan 3.1 Prosedur Penelitian}

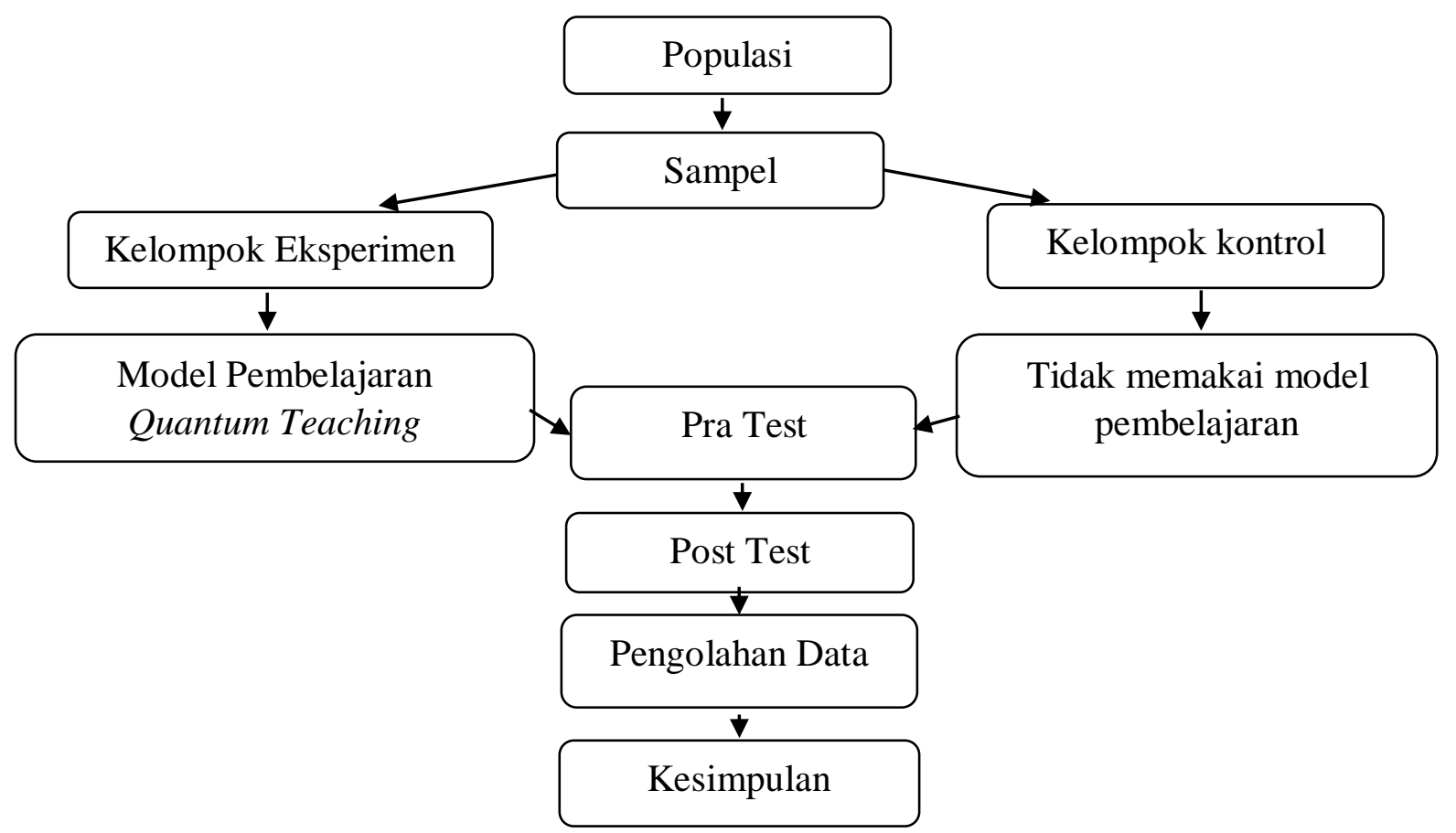

\section{HASIL PENELITIAN DAN PEMBAHASAN}

\section{Pembahasan Hasil Penelitian}

Pada pembahasan ini akan diuraikan temuan penelitian yang telah dianalisis dan dideskripsikan sebelumnya. Adapun yang akan dibahas pada bagian ini yaitu tentang model pembelajaran Quatum Teaching dengan model pembelajaran konvensional.

\section{Hasil Pengaruh Nilai Pretest dan Posttest Eksperimen}

Berdasarkan data yang telah diperoleh dari nilai pretest dan posttest pada eksperimen, dapat dilihat mengalami penigkatan, hasil tersebut dapat dilihat pada tabel dibawah ini: 
Hasil Nilai Rata-rata Pretest dan Posttest Kelas Eksperimen

\begin{tabular}{|c|c|c|c|}
\hline No & Jenis tes & Rata-rata & Kategori \\
\hline 1 & Pretest & 58,85 & Kurang \\
\hline 2 & Posttest & 83,61 & Baik Sekali \\
\hline
\end{tabular}

Nilai hasil belajar siswa pada kelas eksperimen mengalami peningkatan, hal ini ditunjukkan dari pengaruh nilai rata-rata pretest dan posttest. Pretest menunjukkan nilai rata-rata 58, 85 dengan kategori yang kurang sedangkan posttest rata-ratanya, 83, 61 dengan kategori sangat baik.

\section{Hasil Nilai Pretest dan Posttest Kontrol}

Dari nilai penelitian yang telah dilaksanakan, peneliti memperoleh nilai hasil belajar siswa pretest dan posttest pada kelas kontrol, hal ini dapat dilihat pada tabel di bawah ini:

Tabel 4.13 Nilai rata-rata pretest dan posttest kelas kontrol

\begin{tabular}{|c|c|c|c|}
\hline No & Jenis tes & Rata-rata & Kategori \\
\hline 1 & Pretes & 56,22 & Kurang \\
\hline 2 & Posttest & 74 & Baik \\
\hline
\end{tabular}

Dari tabel di atas dapat dilihat bahwa nilai posttest lebih tinggi dari pada pretest. Pretest menunjukkan nilai rata-rata 56, 22 dengan kategori kurang sedangkan posttest rata-ratanya 74 kategori baik.

\section{Hasil Pengaruh Nilai Rata-Rata Kelas Eksperimen dan Kelas Kontrol}

Berdasarkan perhitungan hasil penelitian menunjukkan bahwa terdapat nilai rata-rata antara eksperimen yang menggunakan model pembelajaran Quantum Teaching dengan kontrol yang menggunakan model pembelajaran konvensional. Hal ini dapat dilihat pada tabel dibawah ini:

Tabel 4.14 Hasil Nilai Rata-Rata Kelas Eksperimen dan Kelas Kontrol

\begin{tabular}{|c|l|c|c|}
\hline No & Jenis Model Pembelajaran & Rata-rata & Kategori \\
\hline 1 & Quantum Teaching & 83,61 & Baik Sekali \\
\hline 2 & Konvensional & 74 & Baik \\
\hline
\end{tabular}

Dari uji analisis hipotesis yaitu nilai $t_{\text {hitung }}>\mathrm{t}_{\text {tabel }}$, maka hasil perhitungan yang didapat oleh peneliti yaitu $33.035>1,687$ sehingga model pembelajaran 
Quantum teaching dengan model pembelajaran konvensional dinyatakan bahwa hipotesis diterima. Hal ini dibuktikan dari pengaruh nilai rata-rata model pembelajaran Quantum Teaching lebih tinggi dari pada model pembelajaran konvensional $(83,61>74)$.

Kriteria penilaian untuk nilai rata-rata pretest dan posttest dapat dilihat pada tabel di bawah ini:

Tabel 4.15 Kriteria Penilaian

\begin{tabular}{|c|c|}
\hline Kriteria Penilaian & Keterangan \\
\hline $80-100$ & Baik sekali \\
\hline $70-79$ & Baik \\
\hline $60-69$ & Cukup \\
\hline $50-59$ & Kurang \\
\hline $0-49$ & Gagal \\
\hline
\end{tabular}

Sumber: Syah (2017:151)

Berdasarkan perhitungan hasil penelitian menunjukkan bahwa nilai ratarata posttest dengan menggunakan model pembelajaran Quantum Teaching lebih tinggi dari pada dengan menggunakan model pembelajaran konvensional pada pembelajaran daerah tempat tinggalku sub tema keunikan daerah tempat tiggalku di SD Negeri 050600 Kuala.

\section{Pembahasan Hasil Akhir Temuan}

Penelitian ini dilakukan di kelas IV SD Negeri 050600 Kuala pada dua kelas yang dilakukan dengan perlakuan yang berbeda dimana kelas eksperimen dengna menggunakan model pembelajaran Quantum teaching sedangkan di kelas kontrol menggunakan model pembelajaran konvensional. Kedua kelas menggunakan kontrol yang sama yaitu pembelajaran 1 sub tema 2 keunikan daerah tempat tinggalku dan tema daerah tempat tinggalku.

Untuk mengetahui kemampuan awal siswa, penelitian melakukan pretest di kelas eksperimen dan kontrol, dengan jumlah soal pilihan berganda, dan dengan jenis soal yang sama, diperoleh hasil kelas eksperimen dengan rata-rata 58, 85 dan kelas kontrol dengan rata-rata 56, 22 dari hasil pretest tersebut, dapat dikatakan kemampuan awal di dua kelas rendah. 
Setelah melakukan pretest, peneliti menyampaikan materi dengan menggunakan model Quantum Teaching pada kelas eksperimen dan model pembelajaran konvensional pada kelas kontrol.Di akhir pembelajaran, peneliti kembali memberikan posttest untuk mengetahui tingkat keberhasilan.Hasil dari posttest kedua kelas tersebut memiliki peningkatan dari hasil pretest yang diberikan sebelumnya. Hasil posttest kelas eksperimen dengan rata-rata 83,61 dan kontrol dengan rata-rata 74. Dari data tersebut, dapat dikatakan tingkat keberhasilan tertinggi adalah di kelas eksperimen.

Hasil uji normalitas pada taraf signifikansi $(\alpha=0,05)$, dengan kriteria pengujian normalitas yaitu $\mathrm{L}_{\text {hitung }}>\mathrm{L}_{\text {tabel }}$ maka sampel berdistribusi normal. Hasil uji homogenitas membuktikan bahwa adanya pengaruh $F_{h i t u n g}>F_{\text {tabel }}$ maka dapat disimpulkan bahwa data homogeny, dan pada uji hipotesis dengan menggunakan dengan menggunakan uji-t dari perhitungan data yang dilakukan, hasil pengujian $t_{\text {hitung }}>\mathrm{t}_{\text {tabel }}$ yaitu $33.035>1,687$ dengan taraf signifikansi $\alpha=0,05$. Dengan ini membuktikan bahwa adanya pengaruh yang signifikan dari model pembelajaran Quantum Teaching terhadap hasil belajar siswa pada tema daerah tempat tinggalku kelas IV SD Negeri 050600 Kuala.

Berdasarkan hasil data yang diperoleh dari penelitian di SD Negeri 050600 Kuala dapat dikatakan bahwa dengan model pembelajaran Quantum Teaching membuat siswa lebih aktif terlibat dan berlomba dalam menjawab pertanyaan yang dilakukan dengan menggunakan Quantum Teaching di kelas.

\section{PENUTUP}

\section{Kesimpulan}

Berdasarkan pembahasan bab ini peneliti menguraikan simpulan, implikasi keterbatasan penelitian, dan saran yang disusun berdasarkan seluruh kegiatan penelitian mengenai pengaruh model Quantum Teaching terhadap hasil belajar siswa kelas IV SD Negeri 050600 Kuala Tahun Pembelajaran 2018/2019.

1. Pada kelas eksperimen dengan menggunakan model Quantum Teaching materi tema daerah tempat tinggalku sub tema keunikan daerah tempat tiggalku di SD 
Negeri 050600 Kuala Tahun Pembelajaran 2018/2019 kelas IV-B adalah nilai rata-rata posttest 83,61 berada dengan kategori baik sekali.

2. Berdasarkan hasil pengujian koefisien korelasi dapat dilihat bahwa nilai koefisien korelasi sebesar 0,772 artinya $r_{\text {hitung }}(0,772)>r_{\text {tabel }}(0,433)$ maka $\mathrm{H}_{a}$ diterima. Maka terdapat hubungan yang kuat dan terdapat pengaruh antara model Quantum Teaching terhadap hasil belajar di kelas IV SD Negeri 050600 Kuala. dan berdasarkan perhitungan hasil penelitian menunjukkan bahwa terdapat pengaruh model pembelajaran Quantum Teachingterhadap hasil belajar siswa pada tema daerah tempat tinggalku kelas IV SD Negeri 050600 Kuala tahun pembelajaran 2018/2019 dengan $t_{\text {hitung }}>t_{\text {tabel }}$ dimana $33.035>$ 1,687 pada taraf signifikan $\alpha=0,05$. siswa dengan tema daerah tempat tinggalku sub tema keunikan daerah tempat tinggalku. Dengan demikian $\mathrm{H}_{\mathrm{o}}$ ditolak dan $\mathrm{H}_{\mathrm{a}}$ diterima.

\section{Saran}

Berdasarkan hasil penelitian dan kesimpulan yang telah dipaparkan, maka saran yang dapat disampaikan oleh peneliti adalah sebagi berikut:

\section{Bagi Guru}

Diharapkan dapat menerapkan model pembelajaran Quantum Teaching untuk meningkatkan hasil belajar siswa sesuai dengan materi yang diajarkan dan dapat menumbuhkan semangat siswa agar siswa tidak merasa bosan dan jenuh.

\section{Bagi Siswa}

Dengan mengetahui adanya penelitian tentang pengaruh model pembelajaran Quantum Teaching terhadap hasil belajar siswa, diharapkan siswa mempunyai minat belajar yang lebih besar beda dengan belajar sehari-hari serta lebih aktif dan menambah wawasan siswa.

\section{Bagi Peneliti Selanjutnya}

Diharapkan penelitian ini dapat menambah wawasan dalam menggunakan model pembelajaran pada pada saat proses belajar mengajar dengan materi yang berbeda dan sampel yang berbeda. 


\section{DAFTAR PUSTAKA}

Andini, U. F. 2018. Penerapan Model Quantum Teaching Dalam Meningkatkan Hasil Belajar IPA Siswa Kelas IV SD Tukangan Yogyakarta Pada Tahun Pembelajaran 2015/2016. Yogyakarta: Skripsi

Arikunto, Suharsimi. 2016. Dasar-Dasar Evaluasi Pendidikan. Bandung: PT Remaja Rosdakarya

Deporter, Bobbi dkk. 2018. Quantum Teaching. Bandung: Kaifa

Dimyati \& Mudjiono. 2017. Belajar dan Pembelajaran. Jakarta: Rineka Cipta

Fatimah. 2014.Meningkatkan Hasil Belajar Siswa Dalam Pembelajaran IPAdengan Metode Demonstrasi Di kelas V SDN 10 Biau: Jurnal Kreatif Tadulako. Vol. 5 No. 4 hal 85-96

Istirani \& Pulungan. 2018. Ensiklopedia Pendidikan. Medan: Mediapersada

Jihad, Asep.\& Haris, Abdul. 2013. Evaluasi Pembelajaran. Yogyakarta: Multi Pressindo

Mungkur, Siska. 2018. Pengaruh Model Pembelajaran Quantum Teaching Terhadap Kemampuan Membaca Isi Cerita Pendek Pada Pembelajaran Bahasa Indonesia Siswa Di SD Budi Murni 2 Medan Pada Tahun Pembelajaran 2018/2019. Medan: Skripsi

Ngalimun. 2017. Strategi dan Model Pembelajaran. Banjarmasin: Aswaja Pressindo

Ngalimun, dkk. 2017. Strategi dan Model Pembelajaran. Yogyakarta: Aswaja Pressindo

Ningrum, R. S. 2017. Pengaruh Penerapan Model Quantum Teaching Terhadap Hasil Belajar Matematika SiswaKelas IV SD Negeri 06 Metro Barat Pada Tahun Pembelajaran 2016/2017. Lampung: Skripsi

Nirmalasari, Desy. 2014. Penggunaan Model Pembelajaran Quantum Teaching Dalam Meningkatkan Hasil Belajar IPA DI Kelas V SD Negeri 200120 Losungbatu Kec. Padangsidempuan Utara Pada Tahun Pembelajaran 2013/2014. Medan: Skripsi

Noor, Juliansyah. 2013. Metodologi Penelitian. Jakarta: Kencana Prenada Media Group

Purwanto. 2017. Evaluasi Hasil Belajar. Yogyakarta: Pustaka Pelajar 
Purwanto, Ngalim. 2017. Psikologi Pendidikan. Bandung: PT Remaja Rosdakarya

Rusman. 2017. Model-Model Pembelajaran Mengembangkan Profesionalisme Guru. Jakarta: PT Rajagrafindo Persada . 2017. Belajar dan Pembelajaran Berorientasi Standar Proses Pendidikan. Jakarta: Kencana

Riduwan.2010.Skala Pengukuran Variabel-Variabel Penelitian.Bandung: Alfabeta

Sagala, H. Syaiful. 2014. Konsep dan Makna Pembelajaran. Jakarta: Alfabeta

Sanjaya, Wina. 2016. Strategi Pembelajaran Berorientasi Standar Pendidikan. Jakarta: Prenada Media Group

Sudijono, Anas. 2017. Pengantar Statistik Pendidikan. Depok: PT Rajagrafindo Persada

Slameto. 2017. Belajar dan Faktor -Faktor yang Mempengaruhi. Jakarta: Rineka Cipta

Shoimin, Aris. 2016. 68 ModelPembelajaran Inovatif dalam Kurikulum 2013. Yogyakarta: AR-RUZZ MEDIA

Sriwilujeng, Dyah. 2017. Panduan Implementasi Penguatan Pendidikan Karakter. Jakarta: Erlangga

Subekti, Ari. 2016. Belajar dan Daerah Tempat Tinggalku. Jakarta: Kementrian Pendidikaan dan Kebudayaan

Sudjana, Nana. 2016. Penilaian Hasil Proses Belajar Mengajar. Bandung: PT Remaja Rosadkarya

Sudjana, 2017.Media Statistika. Bandung: Tarsito

Sugiyono. 2017. Metode Penelitian Pendidikan Pendekatan Kuantitatif Kualitatif dan $R \& D$. Bandung: Alfabeta

Supramono, Agus. 2016.Pengaruh Model Pembelajaran Quantum Teaching Terhadap Hasil Belajar IPA Siswa Kelas III SD YPS Lawewu Kecamatan Nuha Kabupaten Luwu Timur. Makasar: Jurnal Nalar Pendidikan. Vol. 4 No. 2 hal 78-86

Surahman, Edy.Mukminan. 2017.Peran Guru IPS Sebagai Pendidik dan Pengajar Dalam Meningkatkan Sikap Sosial dan Tanggung Jawab Sosial Siswa SMP. Yogyakarta: Jurnal Pendidikan IPS. Vol. 4 No. 1 hal 2-12 
Syahfi, Fatimah. 2016. Penerapan Model Quantum Teaching untuk Meningkatkan Aktifitas Belajar IPA Siswa kelas V SDN 060822 Pada Tahun Pembelajaran 2015/2016. Medan: Skripsi

Tanjung, D. S. 2016. Pengaruh Model Pembelajaran Kooperatif Tipe Think Pair Share Terhadap Hasil Kemampuan Belajar PKN Siswa Di Kelas IV Di SDN 142428 Padangsidimpuan Pada Tahun Pembelajaran 2015/2016. Medan: Skripsi

Trianto. 2018. Mendesain Pembelajaran Inovatif-Progresif. Jakarta: Kencana Preneda Media Group

Widyastuti, V. 2018.Pengaruh Penerapan Model Quantum Teaching Terhadap Hasil Belajar Tema Indahnya Keragaman Di Negeriku Pada Siswa Kelas IV Di SDN Karangrejo 03 Jember Pada Tahun Pembelajaran 2015/2016. Jember: Skripsi 